\title{
RESPON TEOLOGIS TERHADAP DAMPAK PANDEMIK CORONAVIRUSES DISEASE 2019
}

\author{
Sandra Christina Sahensolar ${ }^{1}$ ), Simon ${ }^{2}$ \\ Universitas Kristen Indonesia ${ }^{1}$, Sekolah Tinggi Teologi Anugrah Indonesia ${ }^{2}$ \\ *)Email Correspondance: andasahensolar95@gmail.com
}

\begin{abstract}
The coronavirus disease 2019 (covid-19) pandemic has had a huge impact on human life. This study highlights how the theological response to the impact caused by covid-19, both in the context of religious and economic rituals. The method used by the researcher is a qualitative method with a literature study approach. The results of the description in this article suggest that the covid-19 pandemic has caused all global communities and various aspects to be seriously affected by this outbreak, In this outbreak, the world economy has slumped, many people have died due to covid-19, and the space for religious rituals has been restricted. In the context of Christian theology, this pandemic can be indicated as the fulfillment of Bible prophecy as John's prophecy in the book of Revelation. Theologically, this plague is a punishment for humans who are willing to exploit nature. This epidemic is also a form of God's warning in the midst of increasingly corrupted human morality, which eases sinful acts without heeding the truth of God's word. This study concludes that the theological response to the covid-19 pandemic is to be more vigilant spiritually and build a life that glorifies God.
\end{abstract}

Keywords: Response, Theology, Covid-19, Religious Rituals, Economic.

Abstraksi: $\quad$ Pandemik coronaviruses disease 2019 (covid-19) telah memberikan pengaruh yang sangat besar dalam kehidupan manusia. Kajian ini menyoroti bagaimana respon teologis terhadap dampak yang ditimbulkan oleh covid-19, baik dalam konteks ritual keagamaan dan ekonomi. Metode yang peneliti yang digunakan adalah metode kualitatif dengan pendekatan studi literartur. Hasil uraian pada artikel ini mengemukakan, pandemi covid-19 menyebabkan semua masyarakat global dan berbagai aspek mengalami dampak parah karena wabah ini, akibat wabah ini ekonomi dunia terpuruk, kematian banyak orang karena covid-19, ruang gerak ritual keagamaan dibatasi. Dalam konteks teologi Kristen pandemik ini dapat diindikasikan sebagai penggenapan nubuatan Alkitab sebagaimana nubuatan Yohanes dalam kitab Wahyu. Secara teologis wabah ini hukuman bagi manusia yang serahkah mengeksploitasi alam. Wabah ini juga sekaligus bentuk peringatan Tuhan di tengah makin rusak moralitas manusia, yang mengentengkan perbuatan dosa tanpa mengindahkan kebenaran firman Tuhan. Penelitian ini memberikan kesimpulan bahwa respon teologis terhadap pandemik covid-19 yaitu dengan semakin berjaga-jaga secara rohani dan membangun kehidupan yang memuliakan Tuhan.

Kata Kunci: Respon, Teologis, Covid-19, Ritual Agama, Ekonomi.

\section{PENDAHULUAN}

Pandemik coronaviruses disease (covid-19) terjadi diawal tahun 2020

hingga sekarang, telah memberikan banyak mengubah kondisi masyarakat global. 
Hal tersebut terlihat melalui penularan pandemik yang begitu cepat menyebabkan banyaknya korban jiwa meninggal, terjadinya huru-hara dibanyak negara karena ketidak-stabilan suasana politik, makin meningkatnya angka kemiskinan karena menyebabkan pengangguran. Hal tersebut ditegaskan oleh Nistha Shrestha bahwa pandemik covid-19 tidak hanya berdampak dalam hal kematian tetapi juga berdampak pada mata pencaharian dan ekonomi penduduk global, berdampak kepada pembangunan di bidang perdagangan, perjalanan. Pandemi telah mengekspos dan memperburuk kesenjangan antara negara-negara berpenghasilan rendah hingga menengah dan negara-negara berpenghasilan tinggi dan maju, dan antara orang miskin dan orang kaya. ${ }^{1}$ Dengan demikian pandemik covid-19 telah memberikan dampak yang merugikan banyak aspek kehidupan manusia.

Indonesia turut merasakan dampak dari pandemik covid-19, dampak signifikan terlihat dalam sektor ekonomi, sosial, pendidikan dan agama. Tingginya jumlah yang terpapar covd-19 menyebabkan Indonesia belum mampu untuk lepas dari status pandemi. Berbagai upaya telah dilakukan oleh pemerintah untuk menekan angka penularan covid-19. Namun informasi yang diberitakan masih menunjukkan pengingkatan paparan covid-19, meskipun Pembatasan Sosial Berskala Besar (PSBB) telah dilakukan. ${ }^{2}$ Upaya lain yang dilakukan pemerintah saat ini adalah pengadaan vaksin. Vaksin diyakini menjadi salah satu saranan banyak negara untuk menuju kehidupan normal baru. Harapan ini didasarkan pada vaksin yang dinilai paling efektif dan ekonomis untuk mencegah dampak serius dari paparan covid-19. Banyak elemen masyarakat mengharapkan tindakan cepat

1 H. I. Harris, "Exposure to lonizing Radiation from Computerized Axial Tomography," CA: A Cancer Journal for Clinicians 28, no. 4 (Agustus 2020): 238, https://doi.org/10.3322/canjclin.28.4.238-a.

2 Sylvia Hasanah Thorik, "Efektivitas Pembatasan Sosial Berskala Besar di Indonesia Dalam Penanggulangan Pandemi Covid-19," 'ADALAH 4, no. 1 (2020): 115-20, https://doi.org/10.15408/adalah.v4i1.15506. 
pemerintah untuk merealisasikan vaksinasi bagi segenap warga Indonesia. ${ }^{3}$ Walau vaksinasi telah dilaksanakan dalam lingkup pemerintah, para pejabat, tenaga medis, instansi negeri maupun swasta dan sebagian masyarakat. Namun, korban paparan covid-19 masih menunjukkan angka kematian yangb inggi. Direktur World Health Organizations (WHO) Tedros mengemukakan keprihatinan terhadap tingkat penyebaran oleh covid-19 di berbagai negara. WHO menghimbau, agar setiap negara-negara tidak lamban dalam menangani dan mengambil langkah secepatnya untuk menangani penyebaran covid-19. ${ }^{4}$ Cepatnya penyebaran covid-19 telah menimbulkan kepanikan massal terutama negara yang berkembang, mengingat sistem kesehatan belum terlalu maju dan modern. Terkait hal tersebut Chinenyenwa menyarankan agar negara-negara di Afrika khususnya di Nigeria harus bergerak cepat dalam merespon secara aktif, dalam meningkatnya kebutuhan pasien yang terinfeksi melalui pengadaan alat-alat perawatan bagi korban yang terpapar. Ini dilakukan karena covid-19 berkembang menjadi keadaan darurat secara mengglobal yang mengarah pada pandemik. ${ }^{5}$

Tingginya penularan covid-19 memberikan dampak serius dari sektor ekonomi dengan makin bertambahnya angka kemiskinan. Hal ini juga berdampak kepada umat Kristen yang mengalami kesulitan dalam perekonomian. Akan tetapi pandemi ini juga menghadirkan realitas adanya pengusaha yang bertambah kaya karena covid-19, secara khusus para pemegang saham dan orang-orang yang

3 Simon Simon dkk., "Participation of Religious Leaders in Helping the Success of the Government's COVID-19 Vaccination Program," Evangelikal: Jurnal Teologi Injili dan Pembinaan Warga Jemaat 5, no. 2 (29 Juli 2021): 235, https://doi.org/10.46445/ejti.v5i2.405.

4 Domenico Cucinotta dan Maurizio Vanelli, "WHO Declares COVID-19 a Pandemic," Acta Bio Medica Atenei Parmensis 91, no. 1 (19 Maret 2020): 157-60, https://doi.org/10.23750/abm.v91i1.9397.

${ }^{5}$ Chinenyenwa Ohia, Adeleye S. Bakarey, dan Tauseef Ahmad, "COVID-19 and Nigeria: Putting the Realities in Context," International Journal of Infectious Diseases 95 (Juni 2020): 279-81, https://doi.org/10.1016/j.jiji.2020.04.062. 
bergerak dalam bidang farmasi. ${ }^{6}$ Pandemi covid-19 telah menimbulkan penderitaan tidak hanya di bidang kesehatan, tetapi juga di bidang ekonomi.

Pandemi covid-19 juga berdampak kepada kehidupan umat beragama secara global, dampak dari pandemik covid-19 menimbulkan kondisi umat beragama tidak leluasan menjalankan ritual-ritual ibadah. Pratama Putra mengemukakan pandemi memaksa kegiatan keagamaan yang ada untuk dapat beradaptasi dengan adanya larangan perkumpulan massa. Para pemimpin rohani mulai dari keuskupan dan gereja diseluruh dunia ramai-ramai membatalkan kegiatan keagamaan. ${ }^{7}$ Besarnya dampak kerugian diberbagai sektor yang ditimbulkan oleh pandemi covid-19 mendorong umat Kristiani perlu menyikapi segala sesuatu dari sudut Pandang Allah melalui iman. ${ }^{8}$

Penelitian memfokuskan tentang respon teologis terhadap dampak yang ditimbulkan oleh covid-19. Respon teologis pada kajian ini tentu bermuara pada teologi Kristen. Penelitian terdahulu berkaitan dengan respon terhadap pandemi covid-19 dalam bingkai teologi Kristen ditulis oleh Roedy Silitonga, ${ }^{9}$ Susanto Dwiraharjo $^{10}$ dan Fernando Tambunan. ${ }^{11}$ Garis besar pokok pembahasan dari

${ }^{6}$ Morenly Marchel Welley, Franky N. S Oroh, dan Mac Donald Walangitan, "PERBANDINGAN HARGA SAHAM PERUSAHAAN FARMASI BUMN SEBELUM DAN SESUDAH PENGEMBANGAN VAKSIN VIRUS CORONA (COVID-19)," JMBI UNSRAT (Jurnal IImiah Manajemen Bisnis dan Inovasi Universitas Sam Ratulangi). 7, no. 3 (10 November 2021): 571-79, https://doi.org/10.35794/jmbi.v7i3.31514.

7 M. Wahyu Pratama Putra dan Kurnia Sari Kasmiarno, "Pengaruh Covid-19 Terhadap Kehidupan Masyarakat Indonesia: Sektor Pendidikan, Ekonomi Dan Spiritual Keagamaan," POROS ONIM: Jurnal Sosial Keagamaan 1, no. 2 (30 Desember 2020): 144, https://doi.org/10.53491/porosonim.v1i2.41.

8 Sari Saptorini, "Christian response amid economic suffering due to the Covid-19 pandemic," Kurios 7, no. 1 (2 Mei 2021): 66, https://doi.org/10.30995/kur.v7i1.253.

${ }^{9}$ Roedy Silitonga, "RESPON GEREJA ATAS PANDEMIK CORONAVIRUS DISEASE 2019 DAN IBADAH DI RUMAH," Manna Rafflesia 6, no. 2 (30 April 2020): 86, https://doi.org/10.38091/man_raf.v6i2.125.

10 Susanto Dwiraharjo, "Konstruksi Teologis Gereja Digital: Sebuah Refleksi Biblis Ibadah Online di Masa Pandemi Covid-19," EPIGRAPHE: Jurnal Teologi dan Pelayanan Kristiani 4, no. 1 (29 Mei 2020): 1, https://doi.org/10.33991/epigraphe.v4i1.145.

11 Fernando Tambunan, "Analisis Dasar Teologi terhadap Pelaksanaan Ibadah Online Pascapandemi Covid-19," EPIGRAPHE: Jurnal Teologi dan Pelayanan Kristiani 4, no. 2 (28 November 2020): 154, https://doi.org/10.33991/epigraphe.v4i2.210. 
yang ditulis oleh para penulis diatas bermuara pada bagaimana teologi Kristen memandang pelaksaan ibadah di rumah pada masa pandemik covid-19. Kebaruan yang ditawarkan penelitian ini adalah bagaimana merespon dampak covid-19 secara teologis. Ruang lingkup pembahasan topik ini dengan memaparkan bagaimana dampak covid-19 terhadap ekonomi dan ritual menjalankan agama.

\section{METODE}

Williams menyebutkan penelitian juga bagian dari proses yang dilakukan secara sistematis, yaitu mendefinisikan tujuan, mengelola data, dan mengkomunikasikan temuan yang terjadi dalam kerangka yang telah ditetapkan dan sesuai dengan pedoman yang ada. Kerangka kerja dan pedoman itu memberi indikasi akan apa yang dimasukkan dalam penelitian, bagaimana melakukan penelitian, dan jenis kesimpulan apa yang mungkin didasarkan pada data yang dikumpulkan. ${ }^{12}$ Tulisan ini menggunakan metode kualitatif dengan pendekatan studi literature (kepustakaan). Pendekataan kepustakaan atau literatur dipilih untuk menjawab pertanyaan penelitian, karena penelitian tersebut hanya dapat dijawab melalui penelitian kepustakaan karena data penelitian yang diperoleh berasal dari sumber perpustakaan. ${ }^{13}$ Sumber utama data pada tulisan ini dari berbagai artikel jurnal. Langkah-langkah dalam penulisan artikel ini, mengumpulkan berbagai referensi, membaca, mendeskripsikan serta menguraikan dan menarik kesimpulan guna menjawab pertanyaan penelitian pada tulisan ini.

${ }^{12}$ Carrie Williams, "Research Methods," Journal of Business \& Economics Research (JBER) 5, no. 3 (7 Februari 2011): 65, https://doi.org/10.19030/jber.v5i3.2532.

13 Mestika Zed, Metode Penlitian Kepustakaan (Jakarta: Yayasan Obor Indonesia, 2008), x. 


\section{HASIL}

Penelitian tentang topik respon teologis terhadap dampak pandemik covid19 memberikan suatu perspektif bahwa dampak covid-19 menimbulkan dampak yang merugikan dalam banyak aspek. Hal ini dapat dilihat dari merosotnya perekonomian setiap negara yang mengakibatkan makin tingginya jumlah kemiskinan. Wabah ini juga menyebabkan berbagai kepercayaan agama tidak leluasa melaksaakan ritual ibadah dengan pertimbangan mencegah agar tidak terjadinya kerumunan manusia guna memperkecil angka penularan. Besarnya dampak buruk yang ditimbulkan oleh pandemi ini dari salah satu perspektif teologi Kristen wabah ini dindikasikan sebagai penggenapan nubuatan Alkitab dalam kitab Wahyu, pandemik covid-19 sebagai pertanda manusia memasuki fase akhir zaman dan peristiwa pandemi covid-19 dari sisi teologis juga sebagai teguran atau peringatan Allah terhadap penduduk global karena semakin buruknya moralitas manusia dengan mengenyampingkan nilai-nilai kebenaran.

\section{PEMBAHASAN}

Respon teologis adalah respon manusia yang menilai realitas beradsarkan sudut padang Allah. Pandemik covid-19 telah menimbulkan banyak dampak, baik ekonomi dan kehidupan agama, sehingga perlu menyajikan data dan konsep dalam menyikapi dampak-dampak dari pandemik covid-19. Respon teologis signifikan dalam konteks manusa yang merasakan dampak secara negatif dari pandemi covid-19, melalui respon teologis yang benar dapat menangkal konsepkonsep pengajaran yang tidak tepat dalam merespon pandemi covid-19. 


\section{Dampak COVID-19 kepada Ekonomi}

Ekonomi adalah semua yang berhubungan dengan kehidupan baik dalam keluarga dan dalam konteks yang lebih luas mencakup bangsa dan dunia. ${ }^{14}$ Mcnulty mendefinisikan ekonomi sebagai kemampuan untuk mendirikan sistem analitis yang ketat pada prinsip persaingan yang sangat mendasar bagi penalaran ekonomi. ${ }^{15}$ Jadi definisi ekonomi yang dimaksud pada tulisan ini adalah ekonomi yang mencakup semua golongan yang tersistem untuk mengarah pada persaingan baik di tingkat nasional maupun global. Wabah pandemi yang terjadi sekarang ini telah menyebabkan hampir semua perekonomian negara-negara di dunia berada pada inflasi, karena perputaran ekonomi tidak berjalan lancar akibat dampak pandemik covid-19. Perekonomian Indonesia sendiri mengalami dampak karena pandemi ini. Caraka dkk. mengemukakan covid-19 memiliki dampak yang parah dan meluas dan hal itu dialami di Indonesia. Bentuk dampak negatif pandemi covid-19 terlihat dalam kerugian ekonomi. ${ }^{16}$ Pendapat senada dikemukakan Yamali bahwa dampak pada sektor ekonomi akibat pandemi covid-19 di Indonesia antara lain terjadinya Pemutusan Hubungan Kerja (PHK), PMI Manufacturing Indonesia, penurunan impor, peningkatan harga (inflasi) serta terjadi juga kerugian pada sektor pariwisata yang menyebabkan penurunan okupansi. Akibat dari hal ini diharapkan pemerintah Indonesia lebih sigap dalam menangani penurunan pertumbahan ekonomi di Indonesia yang diakibatkan dari

14 Iskandar Putong, Economics Pengantar Mikro dan Makro (Jakarta: Mitra Wacana Media, 2013), $\mathrm{X}$.

15 Paul J. McNulty, "Economic Theory and the Meaning of Competition," The Quarterly Journal of Economics 82, no. 4 (November 1968): 639, https://doi.org/10.2307/1879604.

${ }^{16}$ RE Caraka dkk., "Impact of COVID-19 large scale restriction on environment and economy in Indonesia," Global Journal of Environmental Science and Management 6, no. Special Issue (Covid-19) (2020): 65-84, https://dx.doi.org/10.22034/GJESM.2019.06.SI.07. 
pandemi covid-19. ${ }^{17}$

Dampak covid-19 juga melemahkan para pelaku usaha berbasis Usaha Mikro Kecil Menengah (UMKM). Dengan melemahnya sektor usaha berbasis UMKM tentu membuat makin bertambah tingkat kesulitan finansial di tengah masyarakat Indonesia. Sektor UMKM perlu perhatian khusus dari pemerintah karena merupakan penyumbang terbesar terhadap Produk Domestik Bruto (PDB) yang dapat diandalkan dalam penyerapan tenaga kerja di masa pandemi dengan tujuan mensubtitusi produksi barang konsumsi atau setengah jadi. ${ }^{18}$ Dengan berdampaknya usaha sektor UMKM, para pelaku usaha dituntut untuk dapat menyesuaikan diri dan mengkondisikan penjualan produk dan jasa dan perlu adanya perbaikan kualitas produk serta penyesuaian pelayanan untuk dapat menarik konsumen. ${ }^{19}$

Walau mayoritas mesyarakat mengalami dampak parah karena covid-19 di sektor ekonomi, namun ada sebagian pelaku usaha yang masih memperoleh peningkatan ekonomi. Kelompok pelaku usaha yang mengalami peningkatan ekonomi adalah para pengusaha yang memiliki saham-saham yang bergerak dalam bidang farmasi. Welley mengemukakan perusahaan farmasi yang ditunjuk pemerintah untuk mengembangkan vaksin juga merasakan dampak positif dari pandemi ini. Hasil penelitian menunjukkan bahwa terdapat perbedaan yang signifikan antara harga saham PT Kimia Farma (PERSERO) Tbk dengan harga saham PT Indofarma (PERSERO) Tbk sebelum dan sesudah pengumuman

17 Fakhrul Rozi Yamali dan Ririn Noviyanti Putri, "Dampak Covid-19 Terhadap Ekonomi Indonesia," Ekonomis: Journal of Economics and Business 4, no. 2 (8 September 2020): 384, https://doi.org/10.33087/ekonomis.v4i2.179.

18 Maya Intan Pratiwi, "DAMPAK COVID-19 TERHADAP PERLAMBATAN EKONOMI SEKTOR UMKM," Jurnal Ners 4, no. 2 (17 Oktober 2020): 30, https://doi.org/10.31004/jn.v4i2.1023.

19 Wan laura Hardilawati, "Strategi Bertahan UMKM di Tengah Pandemi Covid-19," Jurnal Akuntansi dan Ekonomika 10, no. 1 (17 Juni 2020): 89, https://doi.org/10.37859/jae.v10i1.1934. 
pengembangan vaksin. $^{20}$ Sekalipun ada segelintir mengalami peningkatan ekonomi karena wabah ini, mayoritas wabah ini menyebabkan dampak yang buruk kepada negara, perusahaan, UMKM dan segenap lapisan masyarakat tanah air. Covid-19 telah membuat sektor ekonomi mengalami keterpurukan karena wabah ini menghambat perputaran roda ekonomi baik skala nasional maupun secara global.

\section{Dampak Covid-19 Pada Pelaksaan Ritual Agama}

Hampir satu tahun lebih wabah pandemik covid-19 melanda dunia. Namun bila memandang dari kacamata global, tampaknya pandemik ini belum mereda dalam waktu dekat mengingat ditemukannya jenis varian baru di Eropa. Kasus ini terungkap pertama kali dari seorang pelancong dari Brasil yang tiba di Jepang pada Januari $2021 .^{21}$ Covid-19 adalah penyakit menular yang disebabkan oleh virus SARS-CoV-2. WHO mendefinisikan wabah virus SARS-CoV-2 sebagai ancaman global yang parah dan melanda berbagai negara. ${ }^{22}$ Kasus pandemi covid19 telah menunjukkan dampak besar kepada semua lapisan masyarakat, ditambah banyak juga penyebaran berita tentang pandemik covid-19 di media sosial yang berdampak pada pengaruh perilaku masyarakat dan mengubah kegiatan kehidupan masyarakat global. $^{23}$

Besarnya dampak yang ditimbulkan oleh pandemik covid-19 menyebabkan bergeser dan berubahnya pola umat beragama dalam menjalankan

${ }^{20}$ Morenly Marchel Welley, Franky N. S Oroh, dan Mac Donald Walangitan, "Perbandingan Harga Saham Perusahaan Farmasi Bumn Sebelum Dan Sesudah Pengembangan Vaksin Virus Corona (Covid19)," JMBI UNSRAT (Jurnal IImiah Manajemen Bisnis dan Inovasi Universitas Sam Ratulangi). 7, no. 3 (10 November 2021): 571-79, https://doi.org/10.35794/jmbi.v7i3.31514.

21 Elisabeth Mahase, "Covid-19: What New Variants Are Emerging and How Are They Being Investigated?," BMJ, 18 Januari 2021, n158, https://doi.org/10.1136/bmj.n158.

22 Matteo Cinelli dkk., "The COVID-19 social media infodemic," Scientific Reports 10, no. 1 (2020): 1-10, https://doi.org/10.1038/s41598-020-73510-5.

23 Simon Simon, "Respon Orang Kristen Terhadap Pemberitaan Televisi Mengenai Covid-19," Jurnal Gamaliel: Teologi Praktika 2, no. 2 (2020): 114, https://doi.org/10.38052/gamaliel.v2i2.52. 
ritual keagaman masing-masing. Misalnya dalam konteks kekristenan, pemimpin gereja yang biasa mengadakan Perjamuan Kudus secara tatap muka, karena pandemik covid-19 ada gereja yang mengadakan perjamuan kudus secara virtual sudah diterapkan dalam gereja. Hakh mengemukakan perjamuan kudus secara virtual dapat diikuti oleh masing-masing jemaat. Karena keterikatan kepada tempat ibadah sebagai tempat yang suci untuk menyembah Allah telah diganti dengan penyembahan dalam persekutuan dengan Yesus sebagai Bait Allah yang sejati. Walau jemaat menjalankan perjamuan kudus secara virtual, umat Allah akan tetap memperoleh berkat rohani berupa penguatan iman dalam menghadapi wabah yang sedang terjadi. ${ }^{24}$ Pelaksaan perjamuan kudus secara virtual di masa pandemi ini adalah salah satu respon teologis gereja pada masa pandemik covdi19.

Nurul menuliskan di Indonesia mulai diberlakukan pembelajaran secara daring (dalam jaringan) sejak masa pandemi covid-19. Begitu pula pada bimbingan perkawinan melalui media sosial yang menjadi pilihan masyarakat pada situasi pandemi. Selanjutnya dimasa pandemi covid-19 para pemimpin gereja mengadakan bimbingan pranikah secara virtual. Berdasarkan wawancara terhadap tiga orang responden para pemimpin gereja melakukan bimbingan pranikah secara virtual, pelaksanaan bimbingan pranikah secara virtual tentu tidak ada kesulitan yang ditimbulkan. ${ }^{25}$ Media sosial telah menjadi pilihan utama yang mempermudah bimbingan pranikah dilakukan secara online dengan tujuan meminimalisir pertemuan secara langsung atau tatap muka pada masa pandemi

24 Samuel Benyamin Hakh, "Perjamuan Kudus Virtual di Rumah Anggota Jemaat: Analisis Alkitabiah tentang Kehadiran Allah berdasarkan Yohanes 4:21-24," DUNAMIS: Jurnal Teologi dan Pendidikan Kristiani 5, no. 2 (26 April 2021): 460, https://doi.org/10.30648/dun.v5i2.524.

25 TY, WNK, dan YAA, Penerapan Bimbingan Pranikah Secara Virtual, Virtual, 22 Agustus 2021. 
ini. $^{26}$

\section{Respon Teologis Terhadap Dampak COVID-19}

Salah satu proses perkembangan perekonomian suatu bangsa atau golongan dapat dilihat melalui "agama". 27 Ekonomi dan agama merupakan dua hal yang berdampingan di dalam eksistensi sebuah negara. Pada abad XIX M di Amerika Serikat (AS) agama memengaruhi kebijakan ekonomi utama, karena dasar dari American Economic Association. Richard Ely menyatakan bahwa kebijakan Amerika pada awalnya bertumpu pada Injil, walau pada akhirnya terjadi reformasi mengenai kebijakan ekonomi di $\mathrm{AS}^{28}$

Covid-19 yang terjadi saat ini, turut memengaruhi semua aspek kehidupan umat manusia secara global. Pengaruh COVID-19 yang berdampak pada semua sendi kehidupan manusia, membuat wabah ini direspon dari berbagai sisi. Para scientist menjadi garda terdepan dalam upaya penelitian virus, namun tidak berarti peran dari agama diabaikan dalam mengatasi situasi pandemik covid-19. Model bio-psikososial-spiritual mulai digunakan dalam skala global oleh sebagian dokter bahwa nilai-nilai religius dalam praktik klinis tetap diperlukan. ${ }^{29}$ Simon dkk. menyebut kaum religius mendorong dan mengajak orang lain untuk merefleksikan hidup dalam kaitan agama agar manusia sesemakin menobatkan diri pada Sang Ilahi disituasi pandemi. ${ }^{30}$

26 Syahrul A'dam, "Praktik Bimbingan Perkawinan Melalui Media Sosial Dalam Membentuk Keluarga Sakinah Di Indonesia" (Thesis, Jakarta, UIN Syarif Hidayatullah, 2021), https://repository.uinjkt.ac.id/dspace/handle/123456789/56697.

${ }^{27}$ Mariatul Qibtiyah, "Tingkah Laku Ekonomi-Politik dalam Hegemoni Agama dan Budaya," Jurnal Studi Sosial dan Politik 3, no. 1 (2019): 55, https://doi.org/10.19109/jssp.v3i1.4068.

${ }^{28}$ Sriya Iyer, "The new economics of religion," Journal of Economic Literature 54, no. 2 (2016): 395, https://doi.org/10.1257/jel.54.2.395.

29 Lindsay B Carey, "COVID-19, Spiritual Support and Reflective Practice," Health and Social Care Chaplaincy 9, no. 2 (2021): 147, http://dx.doi.org/10.1558/hscc.42733.

30 Simon Simon dkk., "Pandemi Covid-19 Dalam Perspektif Teologi Pentakosta," Ritornera-Jurnal Teologi Pentakosta Indonesia 1, no. 1 (2021): 65, https://doi.org/10.54403/ritpi.v1i1.5. 
Covid dari sisi agama khususnya perspektif Kristen dapat diuraikan, berdasarkan Alkitab ada yang mengindikasikan pandemik covid-19 merupakan tanda-tanda akhir zaman sebagaimana yang telah dinubuatkan oleh rasul Yohanes dalam suratnya pada Kitab Wahyu. Pengajaran rasul Yohanes tentang Wahyu 6: 1-17 mengenai pembukaan materai satu sampai keenam. Selanjutnya pandangan Kristen lainnya terhadap pandemik covid-19 dari segi agama sebagai penggenapan nubuatan dari pembukaan materia keempat tentang penyakit sampar. Terkait pandangan tersebut Simon Dein dalam tulisannya berjudul "Covid-19 Mental Health And Religion: An Agenda For Future Research" menyatakan sebagian orang Kristen menanggapi peristiwa penyakit pandemik covid-19 telah dinubuatkan di akhir zaman, sebagaimana yang dikemukakan oleh rasul Yohanes pada saat ia berada di Pulau Patmos. Kitab Wahyu telah digunakan untuk menjelaskan peristiwa dunia dalam istilah "akhir zaman". Meskipun timbul ketidaksepakatan di antara para sarjana teologi tentang bagaimana teks itu harus ditafsirkan, banyak orang Kristen mengklaim covid-19 menjadi salah satu bukti malapetaka dalam kitab Wahyu, yang menandakan kedatangan Yesus sudah dekat. $^{31}$ Selanjutnya Brinton menyebutkan bahwa walau kitab Wahyu menggambarkan kehancuran, malapetaka dan kutukan atas dunia, tetapi itu bukanlah kata terakhir dalam Wahyu. Sebaliknya, kitab itu diakhiri dengan visi tentang langit baru dan bumi baru, yaitu pemulihan Taman Eden. ${ }^{32}$ Dengan demikian meskipun ada yang mencoba mengindikasikan covid-19 terkait dengan penyataan Alkitab tentang konsep eskatologis, namun Yesus Kristus dan rasul Paulus tentang menekankan untuk selalu berjaga-jaga (Mat. 24: 42; 1Tes. 5: 6).

31 Simon Dein dkk., "COVID-19, mental health and religion: An agenda for future research" 23, no. 1 (2020): 1, https://doi.org/10.1080/13674676.2020.1768725.

32 Henry G Brinton, "Revelation 21: 1--22: 7," Interpretation 70, no. 1 (2016): 84-86. 
Respon teologis terhadap pandemik covid-19 dari segi agama dapat dipahami dalam sudut pandangan kejatuhan manusia dalam dosa. Keberdosaan umat manusia menimbulkan dampak bagi dunia ciptaan, perilaku dan kebejatan moral manusia pada era Nuh telah menyebabkan penghukuman Allah. Kebejatan moralitas manusia di masa kini semakin banyak, hal tersebut terlihat banyak negara melegalkan hubungan seksualitas lesbian, gay, biseksual dan transgender (LGBT), Pelegalan aborsi, seks bebas, miras dan sebagainya menunjukkan bahwa moralitas masyrakat secara global tidak berdasarkan Kitab Suci. Banyak umat Kristen di Eropa dan Amerika mulai meninggalkan ajaran Alkitab dalam menjalani hidup, namun masih ada umat Kristen konservatif masih memegang teguh finalitas Alkitab sebagai kebenaran mutlak. ${ }^{33}$ Terkait hal tersebut Beagan menuliskan bahwa banyak kaum LGBT meninggalkan agama formal karena kaum LGBT merasa agama telah menyebabkan penderitaan dan diskriminasi. ${ }^{34}$ Terkait dengan dosa moral, maka ada indikasi pandemik covid-19 dapat dimaknai sebagai bentuk kemarahan Allah karena perbuatan manusia yang lebih dominan pada dosa dibandingkan hidup benar. Alkitab menulis murka Allah nyata atas segala perbuatan kefasikan yang dilakukan oleh manusia. Bentuk perbuatan kefasikan itu bersikap durhaka, tidak menghormati kekudusan Allah, melakukan persetubuhan secara tidak wajar, karena itulah Allah memurkai manusia (Lih. Rm. 1: 18-32). Punt menyebut pada umumnya gereja dan para penentang LGBT, menggunakan kitab Roma pasal satu sebagai dasar biblika untuk berpegang teguh bahwa homoseksualitas pada dasarnya perbuatan dosa yang terlarang. Karena itu teks

33 Claire D Rhodes dan Craig O Stewart, "Debating LGBT workplace protections in the bible belt: social identities in legislative and media discourse," Journal of homosexuality 63, no. 7 (2016): 904, https://doi.org/10.1080/00918369.2015.1116341.

34 Brenda L Beagan dan Brenda Hattie, "Religion, spirituality, and LGBTQ identity integration," Journal of LGBT Issues in Counseling 9, no. 2 (2015): 92, https://doi.org/10.1080/15538605.2015.1029204. 
Roma pasal satu dipandang sebagai kutukan kepada setiap orang yang melakukan hubungan homoseksual. Penggunaan teks Roma pasal satu sebagai penegasan bahwa kaum heteroseksual, posisi mereka lebih tinggi derajatnya di hadapan Allah. ${ }^{35}$

Respon teologis terhadap pandemik covid-19 dapat dilihat sebagai cara Tuhan mengistirahatkan bumi sejenak yang sudah mulai rusak parah karena ulah manusia yang mengeksploitasi alam secara berlebihan. ${ }^{36}$ Alam mengalami kerusakan karena manusia memosisikan diri sebagai tuan yang berhak mengambil kekayaan alam, dan setelah itu tidak ada keinginan untuk memperbaiki kembali alam yang rusak itu. Hasrat manusia yang ingin mengusai alam memunculkan tegangan antara relasi manusia dengan alam hingga berdampak pada seluruh aspek keberadaan manusia. ${ }^{37}$ Namun dengan peristiwa pandemik covid-19 membawa perbaikan karena emisi gas rumah kaca, konsumsi bahan bakar fosil, lalu lintas udara, darat dan laut secara drastis telah menurun, selanjutnya lapisan ozon semakin baik, berkembangnya keanekaragaman hayati dan kualitas udara makin membaik. Dengan adanya social distancing, lockdown dan work form home, maka bumi seakan memulihkan dirinya dari ekploitasi manusia. Terkait hal tersebut Rupani mengemukakan bahwa meskipun krisis pnademik covid-19 telah meluas dan mengakibatkan penderitaan manusia di seluruh dunia, namun tingkat polusi udara menurun karena manusia berfokus memerangi virus, serta makin

\footnotetext{
35 Jeremy Punt, "Romans 1: 18-32 amidst the gay-debate: Interpretative options," HTS Teologiese Studies/Theological Studies 63, no. 3 (2007): 956, https://www.ajol.info/index.php/hts/article/view/148543.

36 Rob Wallace, Matinya Epidemiolog Ekspansi Modal dan Asal-Usul Covid-19 (Yogyakarta: Penerbit Independen, 2021), $x$.

37 Simon Simon, "Peranan Pendidikan Agama Kristen Menangani Masalah Ekologi," EDULEAD: Journal of Christian Education and Leadership 2, no. 1 (2021): 17, https://doi.org/10.47530/edulead.v2i1.60.
} 
bertambah bersihnya udara yang berdampak pada Kesehatan paru-paru. ${ }^{38}$

Perintah Allah di dalam Alkitab agar manusia memelihara bumi (Kej. 1: 26) sering sekali disalah-mengerti orang Kristen untuk menguasai ciptaan Tuhan. ${ }^{39}$ Kesalahmengertian mandat Allah untuk menguasai bumi menimbulkan timbulnya sifat keserakanan yang menyebabkan rusaknya alam dan lingkungan. James L menyebut sebagian teolog dan pemimpin gereja telah menanggapi pentingnya kesadaran pemeliharaan lingkungan. Karena itu, orang Kristen dalam hal ini para pemimpin gereja perlu menekankan kepada jemaat untuk menghimbau agar makin memiliki kesadaran untuk merawat lingkungan di mana berada. ${ }^{40}$ Respon teologis terhadap pandemik covid-19 signifikan untuk menjaga orang percaya memandang Allah dengan benar pada konteks penderitaan.

\section{KESIMPULAN}

Pandemik covid-19 yang masih berlangsung sampai masa kini telah menyebabkan kesusahan secara universal bagi semua orang. Dampak wabah ini telah menghantam semua aspek-aspek kehidupan masyarakat global. Aspek ekonomi membuat setiap negara mengalami penurunan perekonomian, para pengusaha melakukan PHK terhadap pegawai demi menjaga agar tidak bangkrut secara total. Besarnya dampak yang ditimbulkan wabah ini terhadap ekonomi membuat makin bertambahnya jumlah kemiskinan banyak orang. Pandemik covid-19 juga menyebabkan berbagai agama kesulitan dan tidak leluasa

38 Parveen $\mathrm{F}$ Rupani dkk., "Coronavirus pandemic (COVID-19) and its natural environmental impacts," International Journal of Environmental Science and Technology 17, no. 11 (2020): 4655-66, https://doi.org/10.1007/s13762-020-02910-x.

39 Frets Keriapy, "Ekologi Dalam Perspektif Iman Kristen (Mengungkapkan Masalah Ekologi Indonesia)," SIAP 7, no. 1 (2019): $x$.

40 James $L$ Guth dkk., "Faith and the environment: Religious beliefs and attitudes on environmental policy," American Journal of Political Science, 1995, 364-82, https://doi.org/10.2307/2111617. 
menjalankan ritual-ritual keagamaan. Pandemi covid-19 telah mengurangi mobilitas dan kerumunan. Parahnya dampak yang ditimbulkan oleh pandemik covid-19 turut mengundang banyak pihak untuk merespon dan mengkaji. Dari sisi teologis, wabah ini tentu ada yang meyakini sebagai penggenapan nubuatan Alkitab sebagaimana yang tertulis dalam kitab Wahwu bahwa manusia akan diperhadapkan dengan timbulnya berbagai penyakit sampar sebagai tanda memasuki fase akhir zaman. Wabah ini juga dalam bingkai teologis sebagai teguran Allah kepada masyarakat global karena kecenderungan manusia melakukan perbuatan dosa. Pandemik covid-19 juga sekaligus sebagai refleksi kepada manusia untuk tidak serakah terhadap sumber daya alam. Dengan pandemik covid-19 yang merenggut jutaan nyawa manusia, maka manusia dingatkan mulai membenahi diri secara moral dan spiritual.

\section{DAFTAR PUSTAKA}

A'dam, Syahrul. "Praktik Bimbingan Perkawinan Melalui Media Sosial Dalam Membentuk Keluarga Sakinah Di Indonesia." Thesis, UIN Syarif Hidayatullah, 2021. https://repository.uinjkt.ac.id/dspace/handle/123456789/56697.

Beagan, Brenda L, dan Brenda Hattie. "Religion, spirituality, and LGBTQ identity integration." Journal of LGBT Issues in Counseling 9, no. 2 (2015): 92-117. https://doi.org/10.1080/15538605.2015.1029204.

Brinton, Henry G. "Revelation 21: 1--22: 7.” Interpretation 70, no. 1 (2016): 8486.

Caraka, RE, Y Lee, R Kurniawan, R Herliansyah, PA Kaban, BI Nasution, PU Gio, RC Chen, T Toharudin, dan B Pardamean. "Impact of COVID-19 large scale restriction on environment and economy in Indonesia." Global Journal of Environmental Science and Management 6, no. Special Issue (Covid-19)

(2020): 65-84. https://dx.doi.org/10.22034/GJESM.2019.06.SI.07. 
Carey, Lindsay B. "COVID-19, Spiritual Support and Reflective Practice." Health and Social Care Chaplaincy 9, no. 2 (2021): 147-53. http://dx.doi.org/10.1558/hscc.42733.

Cinelli, Matteo, Walter Quattrociocchi, Alessandro Galeazzi, Carlo Michele Valensise, Emanuele Brugnoli, Ana Lucia Schmidt, Paola Zola, Fabiana Zollo, dan Antonio Scala. "The COVID-19 social media infodemic." Scientific Reports 10, no. 1 (2020): 1-10. https://doi.org/10.1038/s41598020-73510-5.

Cucinotta, Domenico, dan Maurizio Vanelli. "WHO Declares COVID-19 a Pandemic." Acta Bio Medica Atenei Parmensis 91, no. 1 (19 Maret 2020): 157-60. https://doi.org/10.23750/abm.v91i1.9397.

Dein, Simon, Kate Loewenthal, Christopher Alan Lewis, dan Kenneth I Pargament. "COVID-19, mental health and religion: An agenda for future $\begin{array}{lllll}\text { research" } & 23, & \text { no. } & 1 & \text { (2020): }\end{array}$ https://doi.org/10.1080/13674676.2020.1768725.

Dwiraharjo, Susanto. "Konstruksi Teologis Gereja Digital: Sebuah Refleksi Biblis Ibadah Online di Masa Pandemi Covid-19." EPIGRAPHE: Jurnal Teologi dan Pelayanan Kristiani 4, no. 1 (29 Mei 2020): 1-17. https://doi.org/10.33991/epigraphe.v4i1.145.

Guth, James L, John C Green, Lyman A Kellstedt, dan Corwin E Smidt. "Faith and the environment: Religious beliefs and attitudes on environmental policy." American Journal of Political Science, 1995, 364-82. https://doi.org/10.2307/2111617.

Hakh, Samuel Benyamin. "Perjamuan Kudus Virtual di Rumah Anggota Jemaat: Analisis Alkitabiah tentang Kehadiran Allah berdasarkan Yohanes 4:2124." DUNAMIS: Jurnal Teologi dan Pendidikan Kristiani 5, no. 2 (26 April 2021): 460-80. https://doi.org/10.30648/dun.v5i2.524.

Hardilawati, Wan laura. "Strategi Bertahan UMKM di Tengah Pandemi Covid19." Jurnal Akuntansi dan Ekonomika 10, no. 1 (17 Juni 2020): 89-98. https://doi.org/10.37859/jae.v10i1.1934.

Harris, H. I. "Exposure to Ionizing Radiation from Computerized Axial Tomography." CA: A Cancer Journal for Clinicians 28, no. 4 (Agustus 2020): 238. https://doi.org/10.3322/canjclin.28.4.238-a.

Iyer, Sriya. "The new economics of religion." Journal of Economic Literature 54, no. 2 (2016): 395-441. https://doi.org/10.1257/jel.54.2.395.

Keriapy, Frets. "Ekologi Dalam Perspektif Iman Kristen (Mengungkapkan Masalah Ekologi Indonesia).” SIAP 7, no. 1 (2019). 
Mahase, Elisabeth. "Covid-19: What New Variants Are Emerging and How Are They Being Investigated?" BMJ, 18 Januari 2021, n158. https://doi.org/10.1136/bmj.n158.

McNulty, Paul J. "Economic Theory and the Meaning of Competition." The Quarterly Journal of Economics 82, no. 4 (November 1968): 639. https://doi.org/10.2307/1879604.

Ohia, Chinenyenwa, Adeleye S. Bakarey, dan Tauseef Ahmad. "COVID-19 and Nigeria: Putting the Realities in Context." International Journal of Infectious Diseases $95 \quad$ (Juni 2020): 279-81. https://doi.org/10.1016/j.ijid.2020.04.062.

Pratiwi, Maya Intan. "Dampak Covid-19 Terhadap Perlambatan Ekonomi Sektor UMKM." Jurnal Ners 4, no. 2 (17 Oktober 2020): 30-39. https://doi.org/10.31004/jn.v4i2.1023.

Punt, Jeremy. "Romans 1: 18-32 amidst the gay-debate: Interpretative options." HTS Teologiese Studies/Theological Studies 63, no. 3 (2007): 965-82. https://www.ajol.info/index.php/hts/article/view/148543.

Putong, Iskandar. Economics Pengantar Mikro dan Makro. Jakarta: Mitra Wacana Media, 2013.

Putra, M. Wahyu Pratama, dan Kurnia Sari Kasmiarno. "Pengaruh Covid-19 Terhadap Kehidupan Masyarakat Indonesia: Sektor Pendidikan, Ekonomi Dan Spiritual Keagamaan.” POROS ONIM: Jurnal Sosial Keagamaan 1, no. 2 (30 Desember 2020): 144-59. https://doi.org/10.53491/porosonim.v1i2.41.

Qibtiyah, Mariatul. "Tingkah Laku Ekonomi-Politik dalam Hegemoni Agama dan Budaya." Jurnal Studi Sosial dan Politik 3, no. 1 (2019): 55-68. https://doi.org/10.19109/jssp.v3i1.4068.

Rhodes, Claire D, dan Craig O Stewart. "Debating LGBT workplace protections in the bible belt: social identities in legislative and media discourse." Journal of homosexuality 63, no. 7 (2016): 904-24. https://doi.org/10.1080/00918369.2015.1116341.

Rupani, Parveen F, M Nilashi, RA Abumalloh, S Asadi, S Samad, dan S Wang. "Coronavirus pandemic (COVID-19) and its natural environmental impacts." International Journal of Environmental Science and Technology 17, no. 11 (2020): 4655-66. https://doi.org/10.1007/s13762-020-02910-x.

Saptorini, Sari. "Christian response amid economic suffering due to the Covid-19 pandemic." Kurios 7, no. 1 (2 Mei 2021): 61-69. https://doi.org/10.30995/kur.v7i1.253. 
Silitonga, Roedy. "Respon Gereja Atas Pandemik Coronavirus Disease 2019 Dan Ibadah Di Rumah." Manna Rafflesia 6, no. 2 (30 April 2020): 86-111. https://doi.org/10.38091/man_raf.v6i2.125.

Simon, Simon. "Peranan Pendidikan Agama Kristen Menangani Masalah Ekologi." EDULEAD: Journal of Christian Education and Leadership 2, no. 1 (2021): 17-35. https://doi.org/10.47530/edulead.v2i1.60.

_. "Respon Orang Kristen Terhadap Pemberitaan Televisi Mengenai Covid19." Jurnal Gamaliel: Teologi Praktika 2, no. 2 (2020): 114-31. https://doi.org/10.38052/gamaliel.v2i2.52.

Simon, Simon, Stefanus Dully, Tomi Yulianto, dan Adi Prasetyo Wibowo. "Pandemi Covid-19 Dalam Perspektif Teologi Pentakosta." RitorneraJurnal Teologi Pentakosta Indonesia 1, no. 1 (2021): 65-77. https://doi.org/10.54403/rjtpi.v1i1.5.

Simon, Simon, Alfons Renaldo Tampenawas, Joko Santoso, Astrid Maryam Yvonny Nainupu, Semuel Ruddy Angkouw, dan Alvonce Poluan. "Participation of Religious Leaders in Helping the Success of the Government's COVID-19 Vaccination Program." Evangelikal: Jurnal Teologi Injili dan Pembinaan Warga Jemaat 5, no. 2 (29 Juli 2021): 23445. https://doi.org/10.46445/ejti.v5i2.405.

Tambunan, Fernando. "Analisis Dasar Teologi terhadap Pelaksanaan Ibadah Online Pascapandemi Covid-19." EPIGRAPHE: Jurnal Teologi dan Pelayanan Kristiani 4, no. 2 (28 November 2020): 154. https://doi.org/10.33991/epigraphe.v4i2.210.

Thorik, Sylvia Hasanah. "Efektivitas Pembatasan Sosial Berskala Besar di Indonesia Dalam Penanggulangan Pandemi Covid-19." 'ADALAH 4, no. 1 (2020): 115-20. https://doi.org/10.15408/adalah.v4i1.15506.

TY, WNK, dan YAA. Penerapan Bimbingan Pranikah Secara Virtual. Virtual, 22 Agustus 2021.

Wallace, Rob. Matinya Epidemiolog Ekspansi Modal dan Asal-Usul Covid-19. Yogyakarta: Penerbit Independen, 2021.

Welley, Morenly Marchel, Franky N. S Oroh, dan Mac Donald Walangitan. "Perbandingan Harga Saham Perusahaan Farmasi Bumn Sebelum Dan Sesudah Pengembangan Vaksin Virus Corona (Covid-19)." JMBI UNSRAT (Jurnal Ilmiah Manajemen Bisnis dan Inovasi Universitas Sam Ratulangi). 7 , no. 3 (10 November 2021): 571-79. https://doi.org/10.35794/jmbi.v7i3.31514.

Williams, Carrie. "Research Methods." Journal of Business \& Economics Research (JBER) 5, no. 3 (7 Februari 2011): 65-72. https://doi.org/10.19030/jber.v5i3.2532. 
Yamali, Fakhrul Rozi, dan Ririn Noviyanti Putri. "Dampak Covid-19 Terhadap Ekonomi Indonesia." Ekonomis: Journal of Economics and Business 4, no. 2 (8 September 2020): 384-88. https://doi.org/10.33087/ekonomis.v4i2.179.

Zed, Mestika. Metode Penlitian Kepustakaan. Jakarta: Yayasan Obor Indonesia, 2008. 